\title{
Resilience of Traditional Political Institution in Nigeria during Colonial Rule: Owa of Idanre in Historical Perspective
}

\author{
Adebisi David Alade* \\ McMaster University \\ Hamilton, Ontario, Canada
}

Received 09.05.2016, received in revised form 27.05.2016, accepted 13.06.2016

Before the advent of the Europeans in Africa, societies in Nigeria had evolved various systems of traditional political institution based on the peculiarities of their ethnic nationalities. These institutions had full executive, legislative and judicial powers, exerted sovereign control over their subjects and engaged in the mobilisation of their people for developmental purposes within their areas of jurisdiction. Using historical descriptive methodology, this paper puts into proper historical perspective, the roles of traditional rulers in Nigeria during colonial rule. This paper uses Owa of Idanre as a case study and posits that until 1976, traditional rulers controlled local governments in Nigeria, but reforms have since relegated them to a mostly ceremonial role. This paper make bold to argues that while few of the traditional rulers during this period collaborated with the colonialist to further the economic interest of the Europeans in their various domains, their contributions to the socio-economic development of their various communities however cannot be over-emphasised. As such, this paper submits that the place and roles of traditional rulers be accorded proper recognition and definition respectively in the Nigerian constitution in order to help tackle the various socio-political and economic challenges facing the country.

Keywords: Owa, Colonial rule, Traditional rulers, Idanre kingdom.

DOI: 10.17516/1997-1370-2016-9-8-1754-1764.

Research area: politology.

\section{Introduction}

Before the advent of the Europeans in Africa, societies had evolved various system of political administrations based on the peculiarities of their ethnic nationalities. These institutions had full executive, legislative and judicial powers in their different domains and exerted sovereign control over their people (Onoja, 2007: 227-243). These institutions are known as traditional institutions.
Tonwe and Osemwota (2013: 96) opined that it is difficult to provide a universally accepted definition of a traditional institution of authority in Nigeria because of the diversity in the political and administrative components of traditional systems in different parts of the country. Adewumi and Egwurube (1985: 20) notwithstanding contend that traditional institution of authority may be defined as the indigenous polity which existed

(C) Siberian Federal University. All rights reserved

* Corresponding author E-mail address: aladeadebisidavid@yahoo.com 
before the advent of the colonialists and headed by a traditional ruler.

According to A. E. Afigbo, traditional institutions are the custodian of local tradition and customs (Afigbo, 1972: 35). They exercise authority which is obtained according to local customs and traditions. Afigbo emphasises that local administration generally centered on the traditional rulers as the repository of religious, legislative, executive and judicial functions, with a few exceptions. One striking fact is that the geographical spheres of authority of these traditional rulers were essentially localised and no traditional ruler ever had jurisdiction over the entire geographical area of modern Nigeria.

Traditional ruler embodies many indigenous organisations and functions. The organisation and functions include village-level governance, acceptable methods of community resource mobilization, security arrangements, conflict resolution, asset management and lineage organization (Donnelly-Roark et al, 2001: 29). Across Africa, traditional political institutions including spiritual ones were found to be important institutions with responsibilities such as land allocation, conflict resolution and mediation with spirits (Blom, 2000: 16).

The traditional rulers in contemporary Nigerian communities, knowing well of their roles and expectations in their areas of jurisdiction most often deviate from these role and expectations as their roles is not specifically defined in the constitution. It is worthy of note that until 1976, traditional rulers controlled local governments in Nigeria, but reforms have since relegated traditional rulers to a mostly ceremonial role. In their place are democratically elected government councils chairmen. In view of these changes with respect to the roles of traditional rulers in the contemporary Nigerian societies, it is imperative to historically establish the indispensable roles and contributions of traditional rulers to the development of their various communities during the colonial period by way of documenting issues that centers on the thrust of this paper.

\section{Theoretical Framework}

The theoretical framework adopted for the purpose of this study is the liberal political economy approach. Liberal political economy interprets both political and socio-cultural forces as explanatory elements in economic analysis. It is a holistic approach to historical methodology. This approach underscores the enduring relative importance of traditional political institution in political context. Owa colonial Idanre kingdom provides a case study of the conceptual value of this approach.

\section{Tradition of Origin of Idanre Kingdom}

Idanre is one of the major towns in Ondo State of Nigeria. It is about $336 \mathrm{~km}$ from Lagos, and lies between Akure and Ondo town to the South-Southwest and East-East North of both towns respectively (Omole: 2012). The town is made up of the hill top sanctuary which has about 640 steps up the hill with five resting spots; and settlements at the base of the hills. Idanre is one of the most important towns that houses magnificent rocks and hills in Nigeria. The ancient town (Oke-Idanre) yielded about $80.0 \%$ of its landmass to rock outcrops, while about $62.0 \%$ of the new town (Odode Idanre) is occupied by this gigantic phenomenon (Akinsunlola: 1999). Although Oke-Idanre is no longer inhabited, many of the institutions and celebrations of the Idanre people remained tied to remaining buildings and sanctuaries in Old Idanre, which is now revered as the spiritual home of the community (Adeniran, 2012:15).

Oral tradition has it that one of Oghoduwa or Oduduwa's (the father and progenitor of Yoruba people) sons included Oranmiyan and Aremitan- 
Olofin. It is recorded that upon the death of Oduduwa, Olofin led and coordinated a very large collection of followers from Ile-Ife through the jungles with stop-overs at different places until they got to Ufe'ke (National Archive Ibadan, Carter: 1894). After Olofin died, the people of Ufe'ke remained up the hills where they lived virtually in isolation and insulation, thus having no direct contact with human civilisation outside their immediate clime until much later (NAI, Carter: 1894). Another Idanre tradition of origin has it that at the death of Oduduwa, Oranmiyan's ambition to take over leadership in Ile-Ife became an open secret (Interview with Igbatoyo Akinsuyan: 2015) and Oranmiyan developed an innate hatred for Aremitan-Olofin due largely to Aremitan's claim to Oduduwa's throne. This 'legitimate' claim of Aremitan led to an open disagreement and conflict among Oduduwa's settlers at Ife.

The people eventually broke into two factions; the first group led by Olofin-Aremitan while Oranmiyan led the second opposing group (Igbatoyo Akinsuyan: 2015). Olofin and his entourage travelled a fairly long distance into the forest until they came to Utaja or Otaoja. Olofin first gave the name Utaja - meaning the rock used as a market place (NAI, Bovell-Jones: 1934). Olofin quickly discovered that Utaja provided a safety and security he needed for his small group of followers. He made up his mind to make this place his last and permanent abode and called the new settlement, Ufe'ke or Ife-Oke - meaning Ife on the hills (Interview with Adelana Ajayi: 2015). Notable personalities among the small group that left with Olofin, which eventually arrived at Utaja were, Agboogun, Lisa, Ojomu, Egunren, Asalu, Jemiken, Logunro among others. All these leaders settled in different family groups within the same location, each family group forming a compound and each family compound was referred to as $E k u$. A popular saying in Idanre is still, nij' ako wa sibe, elekujeku oghun a do si in (meaning when we first got here (Ufe'ke), we all settled in various family compound). This was the type of settlement established at Ufe'ke and after the death of Olofin, his people continued to settle as Elekujeku (Adelana Ajayi: 2015).

\section{Pre-Colonial Traditional Political Institution in Idanre Kingdom}

During the pre-colonial era, Owa (title of Idanre king) was structurally the traditional head and supreme authority of Idanre kingdom (NAI, 1951:5). He ran the affairs of the kingdom with the aid of Ugha - the Council of Chiefs. The Owa functioned as the head and chairman of the council which meet regularly in the palace at eight days interval (Interview with Chief Ogunsami Folarin: 2015). This council was the central organ of traditional political administration in pre-colonial Idanre kingdom. It fussed both the executive and legislative powers to govern the kingdom since the establishment of the kingdom's monarchy. While it is important to note at this junction that the Ugha council was divided into two different classes: the High Chiefs' level called Eghare and the Lower Chiefs' level called Elegbin or Elegbe chiefs, Idanre pre-colonial traditional political institution was not but without its checks and balances that aimed at preventing any $O w a$ from becoming dictatorial (NAI, 1957: 8).

A close examination of this established traditional political institution under the leadership of Owa and his chiefs, one would see that in the task of governance, Owa in conjunction with his council had to shape appropriate policies, order priorities and generate revenue to meet the needs of their community in the exercise of these functions. In all, Owa as the traditional ruler in the centre and his council of chiefs around him was an embodiment of local administration before the arrival of the British coloniser in Idanre. 


\section{Idanre Traditional \\ Political Institution \\ during the Colonial Period}

Under the reign of $\mathrm{Oba}$ Towurojoye Adegboye Arubiefin I, the twenty-third $O w a$ of Idanre, European Christian missionaries visited Idanre and successfully introduced Christianity into the kingdom and the then completely strange, magical art of reading and writing was also introduced during his reign (NAI, 1951: 28). In 1894, the first white man to visit Idanre (Governor Carter) came during his reign. Carter described the $O w a$ as a:

Decidedly striking personality with a bright intelligent face and vivacious manners, his utterances very rapid and that he (the Owa) emphasises his remarks with much gesticulation. I am surprised and pleased to find so intelligent a ruler at Idanre and it was quite refreshing to make the acquaintance of a West African monarch with a will of his own and capable of impressing it upon his subjects (NAI: 1894).

It was this Owa that ceded Idanre to the British Government by a Treaty in 1894 (Olumakaiye, 2006: 17). After Owa Arubiefin ceded Idanre to the British Government in 1894, a new colonial District Officer established his headquarters in Ondo in 1899 and Ondo Division of which Idanre was a part came into being. Native Administration came into effect (Interview with Akinrodoye Bayo: 2015).

With the advent of colonialism in Idanre kingdom during the late nineteenth century, the British colonial administrators recognised the strategic and influential position occupied by $O w a$ in the traditional political institution in Idanre kingdom. While the colonial administrators had a number of problems among which was limited British personnel, and limited finance to run the country, British colonial policy was to generate cost of running colonies and managing the volatile law and order situations from the colonies themselves. Largely for these reasons, the colonialists avoided attempting any drastic reforms of the traditional political institution in Idanre kingdom. However, in a bid to find reasonable solution to their problems of administering Idanre kingdom as well as other territories in Nigeria, the British colonial administration took steps to put in place a system of indirect rule, as a convenient strategy to govern the people through their respective traditional political institutions and rulers while ensuring close guidance by British administrators. In this way, the allegiance of the people was secured via their traditional rulers (Interview with Chief Jibokun Arifalo: 2015). As a corollary in Idanre kingdom therefore, the colonial government consolidated the role of $O w a$ as chief executive of his locality. This system was used across the British West Africa colonies and was called Indirect Rule.

The system of indirect rule meant that the British would rule through the existing traditional political apparatus of government. To do this successfully in Idanre kingdom, the power and prestige of Owa was enhanced through reform which in turn reduced the authority of the Ugha chiefs. For example, the power of the Ugha which during the pre-colonial era served as a check on the powers of the Owa was reduced, leaving Owa's political authority and power unchecked (Interview with Elder Samuel Omoniyi: 2015). Due to the unrestricted power conferred on Owa by the British colonialist, he was thus in firm control of his councils and tended to be despotic and authoritarian in performing his functions which were essentially maintenance of law and order and enforcement of tax policies of the British colonial government (Onoja, 2007: 227243 and NAI: 1934). 


\section{Challenges of $O w a$ during Colonial Rule}

The colonial government divided Yorubaland into provinces. Each province was sub-divided into divisions and was further broken into districts. Traditionl rulers such as Alaafin of Oyo, Alake of Egbaland, Ooni of Ife, and Awujale of Ijebu were made first class chiefs and also regarded as paramount rulers while other traditional rulers were ranked below these kings (Afigbo, 1972: 15). This indicated that the traditional rulers could make laws on any matter in their domain, although the resident colonial officer must approve such law.

Colonial rule in Nigeria to a considerable extent reduced the dignity and respect of Owa drastically like in other Nigerian traditional societies. As a matter of fact, he was made to be mere titular head of Idanre during the period. In other words, Owa effectively transformed himself from custodian of his people into custodian of the colonial order (Interview with Madam Adeola Arowolo: 2015). This not only eroded his support base, but also overemphasised his coercive functions. More so, frequent interventions by the colonial authorities into traditional and customary matters, coupled with the strategy to employ customary law as a mechanism to enforce the colonial order, transformed the customary into a site of contention and struggle (Akintan, 2014: 293).

Finally, decentralised despotism came into the traditional political institution of Idanre kingdom during the colonial period (Interview with Pa. Ezekiel Olaniyan: 2015). Decentralised despotism meant that Owa was incorporated into state structures. He was paid by the state and performed state functions; hence, Owa became civil servant in most respects (Tonwe and Osemwota, 2013: 99). The fact that Owa acted in the interest of the colonial order pitted him directly against other more progressive social forces that resisted that same order. This paved the way for an inter-elite strife in the postcolonial order of Idanre kingdom as well as in Nigeria as a whole.

\section{Colonial Roles of $\mathrm{Owa}$}

\section{in the Socio-Economic Development of Idanre Kingdom}

More often than not, scholars often misrepresent the role of traditional rulers in the colonisation of Nigeria, particularly their participation in the colonial rule. ${ }^{1}$ They have also been accused of complicity in the sustenance and prolongation of colonial rule in Nigeria for their support for the British colonialists. The fact is that people tend to look at the past with the eyes of the present, thereby seeing the negative sides of the activities of past heroes and heroines who had done what they did in the light of the realities and situations of their time. ${ }^{2}$ In fact, Roland Oliver and J. D. Fage opined that the categorisation of such Africans as saboteurs or collaborators 'hardly fit the circumstances of eighty years ago' (Oliver and Fage, 1970: 49). While it is an established fact that traditional rulers were actively involved in colonial administration, unfortunately, scholars have not emphasised the nationalist role of traditional rulers during the period of colonial subjugation of Nigeria by the British.

Indeed, traditional rulers constituted the early opposition to the colonisation of Nigeria during the period of the 'legitimate' trade which followed the abolition of the Atlantic slave trade (Idrees, 1989: 69-82). They saw the desire of the Europeans to take over the control of the commerce in their domains as an affront against traditions and as the custodians of people's custom, they rose to the occasion by challenging the European domination and control. Because of the European possession of superior fire-arms, almost all these rulers were captured and deported, to enable the Europeans control the commerce of the areas under them, 
while puppets were appointed in their positions (Interview with High Chief Charles O. Akinde: 2015). This deposition and enthronement of traditional rulers by the European officials during this period had disastrous impact on traditional chieftaincy institutions in Nigeria. These challenges however, did not make the traditional rulers agent of retardation and underdevelopment. Rather, they contributed to the socio-political and economic development of their various kingdoms and localities. In the colonial Idanre kingdom, Owa faced many challenges which posed serious threat to the cohesion of his kingdom. Despite these challenges, his importance in the society cannot be over-emphasised.

Public-service delivery in Idanre was not satisfactory generally before the coming of the British colonialist (NAI, 1894: 689). Lack of adequate capacity on the part of the existing precolonial government in the design and delivery of these services was among the major factors that contributed to the poor state of service delivery in Idanre kingdom. However, after the position of Owa was consolidated by the colonialist, the democratisation and incorporation of Idanre traditional political institution into the colonial administration contributed to the improvement of service-delivery in pre-independence Idanre kingdom. Owa mobilised local communities such as Alade-Idanre, Odode-Idanre and Atosin-Idanre for political participation, thereby empowering them to play a part in influencing policy on the distribution of public services (Interview with Chief Baiken Akinbinu: 2015). Owa also supported the efforts of colonial government in service delivery by participating in the administration of justice and by mobilising human and financial resources for expanding educational and health services in the various Idanre villages.

Another area where Owa contributed immensely to the socio-political and economic development of colonial Idanre kingdom was in the area of mitigation of resource-based conflicts. The communal land tenure system that was pervasive in much of pre-colonial Idanre was a foundation for the traditional political structures and democratic values. The communal tenure system created access to land for all members of the Idanre community. While it does not necessarily alleviate poverty or ensure social equality, it created a relative equality of access to land (Igbatoyo Akinsuyan: 2015). With the colonisation of Idanre kingdom, access to land became affected through registration and privatisation of communal land (Olumakaiye, 2006: 29-30). The colonial government which issued land concessions to commercial farmers and mining corporations (with little regard for the land rights and interests of Idanre local communities) caused division in Idanre during this period. Such concessions, in conjunction with population growth and adverse ecological changes, thus led to land shortages and the impoverishment of local communities of Atosin, Alade, Odode and other villages of Idanre kingdom. This triggered violent resource-based conflicts among communities. Owa made use of the local administration, called the Idanre Native Administration to settle all these cases of land dispute (Baiken Akinbinu: 2015). Although superimposed over the local administration for supervisory purposes were the British political and administrative officials which include Resident Officer, District Officer and Assistant District Officer. Owa however, mitigated resource-based conflicts through respect for traditional land rights of local communities and their involvement in decision-making as well as in sharing the benefits of land equally.

Owa was collectively seen as part of human agents God used to sustain cohesion and stabilities in colonial Idanre kingdom (Charles O. Akinde: 2015). Every institution in Idanre society 
was religiously oriented, and religion permeates the whole of man. Every activity is also seen as religious activity. Owa was enthroned to serve the various communities that formed colonial Idanre kingdom and his existence was for the well-being of his subjects. His existence brought unity, peace and harmony into his community during the colonial era (Adeola Arowolo: 2015). Not only did Owa ensured cordial relationship among the different settlements in pre-independence Idanre kingdom for effective and efficient participation in community development programmes, but also maintained peace and harmony between communities that bound Idanre often through trade and marriages.

British officials during the colonial period in Idanre kingdom cannot settle any dispute amicably without the intervention of the $O w a$, since he was the custodian of his people's traditions (Samuel Omoniyi: 2015). Owa settled civil disputes as well as criminal cases in the Native Court established by the colonialist. The idea of classifying cases into either civil or criminal existed among the pre-colonial Idanre people, and a criminal was called odaran. To be considered odaran, one had to commit a heinous offense that could not easily be settled or dismissed as trivial (Samuel Omoniyi: 2015). Such cases included homicides, treason and felony, burglary, accidental or provoked manslaughter, assault, and rape, while civil cases included willful damage of property, quarrel, insult, debt, and other offenses. Owa and the Native Court chiefs passed judgments on such cases. The due punishments depended on the nature of the crime and it was the Owa that could impose capital punishment. Owa's sanction was usually based on a real rather than putative consensus of the community. However, a consensus had to be obtained among the adjudicating chiefs. Since the Owa was seen as the father of all, he was concerned with elements of reconciliation as well as blame, but blame was not paramount as he was concerned with management of disputes within his territory to promote justice and equality.

Owa stood as liaison between governmental/ non-governmental agencies and Idanre kingdom for financial and technical assistance geared towards socio-political and economic development in the colonial Idanre kingdom (NAI: 1959). Owa was responsible for raising funds through levies, donations, launchings and appeals to British colonial government to finance development projects in colonial Idanre. $\mathrm{He}$ provided information to rural people on where and how to obtain farm inputs such as fertilisers, pesticides, credits, seeds, etc as well as informal technical advice to Idanre farmers on how to utilise European farm inputs (Igbatoyo Akinsuyan: 2015). Not only did Owa developed plan of work for the community projects, he also monitored and evaluated projects for proper implementation as well as diffusing and educating Idanre people on government/non-government intentions for the kingdom. Moreover, Owa ensured that all assistance from government/non-government agencies reached the targeted communities in the kingdom, while he also coordinated all colonial rural development projects in Idanre to ensure that results were achieved.

Since the British colonialist brought Christianity along with them to Idanre kingdom, and Islam not well established by this time; Owa most of the time, participated actively in the worship of the Almighty God in the church, while he was also the head of the traditional religion worshippers (Adelana Ajayi: 2015). Owa balanced everything in his domain to confirm the belief that traditional rulers have no religion of their own. Owa also enhanced interreligious dialogue by promoting religious harmony, freedom and tolerance in colonial Idanre kingdom.

Owa was regarded in colonial Idanre as the custodian of the people's history and culture. 
Owa personified the kingdom and represented the reincarnation of the past ancestors of the community. Therefore, Owa appeared in public during important traditional festivals and religious celebrations to perform rituals and bless the people as his political position was not only divine, but it was also based on ritual leadership (NAI, 1934: 2). In other words, Owa was seen by his people as the symbol of the people's past, custodian of their history and past, upholder and preserver of their culture and customs, epitome of cultural norms and values of the society such as truth, discipline, courage and responsibility. Thus, Owa participated in different festivals, rituals and ceremonies in colonial Idanre kingdom which created unity, love and oneness among the Idanre communities despite the division that indirect rule brought between the Owa and his people.

The early British settlers in colonial Idanre kingdom recognised the importance of the establishment of law and order if they would succeed in colonising Idanre. And for law and order to be accepted by the people, they felt that there was the need to preserve the existing political and judicial institution which revolved around the $O w a$ as much as possible. Hence, Native Court was established for the preservation and enforcement of customs and laws (NAI: 1934). Thus, under the British colonial administration in Idanre kingdom, customary court was set up to replace the traditional court (the Owa's court). However, this replacement did not relegate the resourcefulness and significance of Owa, who was placed at the helms of affairs in the Native Court along with persons that the colonial government regarded as chiefs of other communities within Idanre since they no longer had the power of holding private courts in their own respective palaces and compounds (Akintan: 2014:329). Their aim was to prevent fines and punishment from being imposed in their courts arbitrarily. Thus, Owa maintained law, customs and orderliness through the colonial Native Court throughout the colonial period in Idanre kingdom. Moreover, Owa enforced colonial government laws such as tax and rate payments through dialogue and persuasion, which consequently promoted developmental projects within Idanre kingdom.

\section{Conclusion}

Although, lack of formal education and seldom abuse of office on the part of some traditional rulers, coupled with frequent intervention of British colonial officers (who lacked respect for the traditional political institution and custom of the people) in some areas of the colonial Nigeria adversely affected the indigenous political institution; it should be noted that traditional rulers across Nigeria occupied important position in the colonial period. Be that as it may, Owa like other traditional rulers in colonial Nigeria, was instrumental in the socio-political and economic development of his kingdom till independence and after.

In the build up to the 2015 General Election, political parties and their flag bearers dragged traditional rulers into the wind of electioneering campaign that blew across the country. This was done in the light of the huge influence these rulers have on their people. As a matter of fact, a negative word about any political party from them could spell doom for such party. This paper thus make bold to argue that the welfare and interest of the people would be better served if these traditional rulers are given more political role within the constitution.

While the input of traditional rulers in the fight against the Boko Haram insurgency in contemporary Nigeria could go a long way to help end the menace that has reduced the inflow of foreign investments in the country; these unrecognised traditional rulers could as well play a major economic role in mobilising their 
communities towards large-scale agriculture in line with the Federal Government policy of economic diversification from its current overdependence on the oil and gas sector. This is hoped will ultimately reduce unemployment, crime-rate, high cost of living and engender unprecedented increase in local production.
Without doubt, these will move the country rapidly towards socio-economic development the country urgently needs. Hence, the need for proper definition of traditional rulers' roles in the country's constitution to enable them plays active part in moving the country forward.

\footnotetext{
1 A school of thought concerning the role of different indigenous interest groups in European conquest of Africa views those Africans who sided with Europeans as nothing but saboteurs, traitors, quislings and unpatriotic elements that aided colonialism. See: Pallinder, A. (1978). "Nigeria and the British". Journal of African History: 19(3), pp. 468-469.

2 Those Africans who sided with the Europeans were merely reacting to the prevailing circumstances of inter and intragroup rivalries in which the weak groups tried to use the European factor to achieve their aims. For instance, Obaro Ikime is of the opinion that though those Africans who sided with the Europeans facilitated colonialism, 'it is important to appreciate the fact that they did not necessarily see themselves as saboteurs or collaborators...such groups or individuals were merely seeking to use the British as allies for the promotion of their own interests'. See: Ikime, O. (1977). The Fall of Nigeria. London: Heinemann Educational Books Ltd, p. 211.
}

\section{References}

Adeniran, A. (2012). “The Many Enchantments of Idanre Hills”. The Guardian Nigeria: Saturday 7 April. 15.

Adewumi, J. B. and Egwurube, J. (1985). "The Roles of Traditional Rulers in Local Government: Historical Perspective.” In: Aborisade, O. (Ed.) Local Government and Traditional Rulers in Nigeria, Ile-Ife: OAU Press. 20.

Afigbo, A. E. (1972). The Warrant Chiefs. London: Longman. 35.

Akinsunlola B. T (1999). The Effects of Rock outcrops on Settlement pattern of Idanre, Ondo State. Unpublished B.Tech Thesis submitted to the Department of Urban and Regional Planning, Federal University of Technology. Akure, Ondo State.

Akintan, A. S. (2014). A History of Idanre (Ufe'ke): Earliest Times to the Present. Ibadan: John Archers. 293.

Blom, A. (2000). "Ambiguous Political Space: Chiefs, Land and the Poor in Rural Mozambique". Roskilde University Journal of International Development Studies: 2(1), 16

Donnelly-Roark, P., Ouedraogo, K. and Ye, X. (2001). Can Local Institutions Reduce Poverty? Rural Decentralization in Burkina Faso. Africa region: Environmental and Social Development Unit. 29

Idrees, A. A. (1989). "Collaboration and the British Conquest of Bida in 1798: The Role and Achievement of Indigenous Interest Groups". African Study Monographs, Department of History, University of Ilorin: 10(2), 69-82.

Ikime, O. (1977). The Fall of Nigeria. London: Heinemann Educational Books Ltd, 211.

Interview with Chief Igbatoyo Akinsuyan, 62 years, Retired Civil Servant at Itogun quarters, Idanre on $4^{\text {th }}$ May, 2015.

Interview with Adelana Ajayi, 79 years, Businessman at the Olu of Awure's Palace, Usen, Edo State on $3^{\text {rd }}$ May, 2015.

Interview with Chief Ogunsami Folarin, 85 years, Retired Civil Servant at No 41, Atosin-Idanre, Idanre on $10^{\text {th }}$ May, 2015. 
Interview with Akinrodoye Bayo, 92 years, Farmer at Oja'dale, Odode-Idanre, Idanre on $11^{\text {th }}$ May, 2015.

Interview with Chief Jibokun Arifalo, 72 years, Ifa Priest at Isalu quarters, Idanre on $16^{\text {th }}$ April, 2015.

Interview with Elder Samuel Omoniyi, 64 years, Civil Servant at Irewole quarters, Alade-Idanre, Idanre on $10^{\text {th }}$ May, 2015.

Interview with Madam Adeola Arowolo, 68 years, Trader at Alade market, Idanre on $10^{\text {th }}$ May, 2015.

Interview with Pa. Ezekiel Olaniyan, 80 years, Pastor at Broad Street, Odode-Idanre, Idanre on $11^{\text {th }}$ May, 2015.

Interview with High Chief Charles O. Akinde, 75 years, Researcher/Publisher at No. 222, Broad Street, Odode-Idanre, Idanre on $10^{\text {th }}$ May, 2015.

Interview with Chief Baiken Akinbinu, 54 years, Ifa Priest and leader of Orosun, at Odode, Idanre on $28^{\text {th }}$ May, 2015.

National Archive, Ibadan (NAI): (1894). CO/147/98/18450: Governor G. T. Carter's on His Tour of the Idanre Country.

NAI: (1934). File No. 10996, Bovell-Jones, T. B. Intelligence Report on the Idanre District in the Ondo Division of the Ondo Province.

NAI, (1951). File No. 9812/299, Akure-Idanre Affairs, Secretary, Western Provinces, Letter to the Chief Secretary to the Government on $2^{\text {nd }}$ of July, Lagos, 5

NAI: (1957). Customary Law Regulating the selection of the Owa of Idanre Chieftaincy, Chief Law. 8.

NAI: (1894) Confidential Dispatch to Lord Ripon, Secretary of State for the Colonies, the Foreign Office, London, Paragraph 7. 689.

NAI: (1959). Chiefs Law of Western Nigeria.

Oliver, R. and Fage, J. D. (1970). "The Futility of Resistance, the Success of Collaboration". In: R. O. Collins (ed.) Problems in the History of Colonial Africa, 1860-1960. Englewood Cliffs: Prehtice Hall Inc., 49.

Olumakaiye, T. A. (2006). Oniserere: A Short History of an Idanre Community. Lagos: Bahfik Publishers. 17.

Omole, F. K and Owoeye, J. O. (2012). "Impact of Rocky Topography on Settlement Pattern and Housing Development in Idanre, Nigeria”. Mediterranean Journal of Social Sciences: 3(3).

Onoja, A. (2007). "Redefining Tradition: The Chieftaincy Institution in Nigeria". Ife Journal of History: 4(2), 227-243.

Pallinder, A. (1978). "Nigeria and the British". Journal of African History: 19(3), 468-469.

Tonwe, D. A. and Osemwota, O. (2013). "Traditional Rulers and Local Government in Nigeria: a Pathway to Resolving the Challenge". Commonwealth Journal of Local Governance: 13(14), 96. 


\title{
Устойчивость традиционного
}

\author{
политического института в Нигерии \\ в период колониального господства: \\ Ова в Иданре в исторической перспективе
}

\author{
Адебиси Дэвид Эладе \\ Университет МакМастер \\ Гамильтон, Онтарио, Канада
}

\begin{abstract}
До появления европейцев в Африке общества в Нигерии развивались в виде различных систем традиционных политических институтов, основанных на особенностях этнических групп. Эти институть имели полную исполнительную, законодательную и судебную власть, оказывали суверенный контроль над своими подданными и осуществляли мобилизацию своих людей в целях развития в рамках своей юрисдикции. Используя исторический описательный метод, в данной статье рассматривается роль традииионных правителей Нигерии в период колониального господства с точки зрения правильной исторической перспективы. Ова в Иданре приводится в качестве примера. В статье утверждается, что до 1976 года традиционные правители контролировали местные органы власти в Нигерии, но реформы, проведенные с тех пор, свели их роль на церемониальную. Предполагается, что в то время как некоторые из традиционных правителей в течение этого периода сотрудничали с колонизаторами, повышая дальнейшую экономическую заинтересованность европейцев в различных областях, их вклад в социальноэкономическое развитие их общин, тем не менее, нельзя переоценить. Таким образом, месту и роли традиционных правителей должно уделяться надлежащее внимание и определение в соответствии с конституцией Нигерии с иелью решения различных сочиально-политических и экономических проблем, стоящих перед страной.

Ключевые слова: Ова, колониальное господство, традиционные правители, королевство Иданре.
\end{abstract}

Научная специальность: 23.00.00 - политология. 